$3-1-2020$

\title{
Manufactured Insecurity: Mobile Home Parks and Americans' Tenuous Right to Place. By Esther Sullivan. Berkeley: University of California Press, 2018. Pp. xiv+264. \$85.00 (cloth); 29.95 (paper).
}

\author{
Ranita Ray \\ University of Nevada, Las Vegas, ranita.ray@unlv.edu
}

Follow this and additional works at: https://digitalscholarship.unlv.edu/sociology_pubs

Part of the American Literature Commons, and the Inequality and Stratification Commons

\section{Repository Citation}

Ray, R. (2020). Manufactured Insecurity: Mobile Home Parks and Americans' Tenuous Right to Place. By Esther Sullivan. Berkeley: University of California Press, 2018. Pp. xiv+264. \$85.00 (cloth); 29.95 (paper).. American Journal of Sociology, 125(5), 1456-1458.

http://dx.doi.org/10.1086/708029

This Book Review is protected by copyright and/or related rights. It has been brought to you by Digital Scholarship@UNLV with permission from the rights-holder(s). You are free to use this Book Review in any way that is permitted by the copyright and related rights legislation that applies to your use. For other uses you need to obtain permission from the rights-holder(s) directly, unless additional rights are indicated by a Creative Commons license in the record and/or on the work itself.

This Book Review has been accepted for inclusion in Sociology Faculty Publications by an authorized administrator of Digital Scholarship@UNLV. For more information, please contact digitalscholarship@unlv.edu. 
unpredictability for Muslim Americans within their daily lives but also emphasizes the power dynamics in society, as some are empowered and even encouraged to surveil others. Chapter 5 discusses how surveillance of Muslim Americans has impacted the place of South Asian and Arab Muslim Americans on the racial hierarchy and illustrates how religion and gender influence their position. Given that many of Selod's participants were born in the United States, this raises questions about who belongs and who is included and who is excluded as citizens.

The conclusion is forward thinking and speculates the fate of Muslim Americans especially given the anti-immigrant, anti-Muslim rhetoric of the presidential campaign of Donald Trump in 2016, which continues to come through in his administration's more recent policies.

I found Forever Suspect to be well researched and to provide a rich account of the experiences of two communities of Muslim Americans after September 11 without being too generalizing or overreaching. I appreciated Selod's careful use of interview quotes in the middle chapters to underscore how race, gender, and religion are confounded politically and socially in the War on Terror as well as the challenges that Muslim Americans face in their everyday lives due to increased surveillance at the state and community levels.

I would be interested to know how the experiences of Arabs and South Asians compared to other Muslim Americans who do not identify as suchfor instance, those who identify as having European heritage or those who identify as African or African-American. However, that was outside of the scope of this book, and I do hope this would be a topic of a future text. At first it may appear that Forever Suspect rehashes some long-standing queries in the social sciences about race, culture, and religion, but its application of these questions within the context of the contemporary urban United States is welcomed. This book will be of interest to a wide range of scholars and students interested in topics such as race, the state, immigration, nationalism, performativity, citizenship, and public policy and comes at a critical time when inclusion/exclusion seems to be a key political question.

Manufactured Insecurity: Mobile Home Parks and Americans' Tenuous Right to Place. By Esther Sullivan. Berkeley: University of California Press, 2018. Pp. xiv+264. $\$ 85.00$ (cloth); 29.95 (paper).

Ranita Ray

University of Nevada, Las Vegas

Traditionally, ethnographers of urban poverty in the United States have tended to write about the everyday lives, tentative morality, and curious practices of the "poor" as if poverty were a surprise outcome of illusive structures and intensely complex behaviors of the poor. In recent times, there has been a welcome intervention by ethnographers invested in underlining the relational nature of poverty and the rather direct role of the racially and 
economically privileged in fostering the dire conditions of those living on the margins of society. Esther Sullivan's Manufactured Insecurity is within this lane, offering us a careful investigation of the business of poverty housing and a welcome addition to the growing sociology of eviction. Housing insecurity, as Sullivan and other sociologists studying eviction have highlighted, continues to remain on the margins of poverty research agenda, yet tenuous housing threatens basic human dignity, criminalizes the already marginalized, and fosters negative health and educational outcomes.

In Manufactured Insecurity, Esther Sullivan poignantly highlights, and elegantly analyzes, the everyday reality of tenuous housing that impacts millions of economically marginalized residents of mobile home parks in the United States. Sullivan skillfully underlines both the sociohistorical processes and contemporary policies and economic landscape that have shaped a unique set of property rights of residents of mobile home parks - the majority (almost $80 \%$ ) of residents own their mobile homes, but they have to rent the lots. The "halfway homeowners" are thus beholden to private landlords, have no protection against rent increase, and can be evicted at any time.

Sullivan draws on an impressive range of data including ethnographic observations gathered from following 180 evicted residents throughout 32 parks in Texas and Florida, observations and interviews with various stakeholders, and macrolevel geospatial analysis. This allows Sullivan to theorize mass eviction as a multidimensional phenomenon highlighting the relational nature of the production and reproduction of poverty. While many ethnographers shy away from historicizing and contextualizing the "thick descriptions" and everyday lives of their research participants, Sullivan boldly makes the analytical jump and attempts to locate individual stories of eviction, stigma, and suffering as part of the "neoliberal" agenda that contours private market solutions to housing insecurity. Keeping up with ethnographic traditions, Sullivan also moved into mobile homes to live side by side with her research participants and is careful to stress that this did not mean that her experience had any resemblance to the suffering or insecurities the participants underwent. While the ethics, and necessity, of moving into homes right before eviction does not leave me completely comfortable, I do recognize the methodological payoffs of doing so.

The chapter on the regulations that have historically shaped the development of mobile home parks as a unique American housing invention brilliantly contextualizes the housing insecurity that characterizes mobile home residents. Sullivan's innovative attempt to triangulate geospatial analysis with observations conducted during rezoning debates provides a unique set of insights into mobile home park closures as tied to the construction of "trailer trash" as second-class citizens. Sullivan also nicely intervenes in gentrification debates to highlight how not only residents, but whole urban structures, can be evicted.

I was particularly intrigued by Sullivan's concept of the "specter of dislocation," which captures how housing insecurity pervades the life of mobile home park residents-beginning with the uncertain relationship with their 
homes (residents do not own the land on which their homes sit) to the threat of eviction. This provides the context within which residents come to understand the meaning of home and community, as well as themselves as citizens. Sullivan contextualizes the mobile home park closures within the larger threat of displacement that haunts those who live on the margins. But in this postcolonial reality, displacement of black and brown bodies is often theorized by many as an outcome of Western imperialism-how "trailer trash" comes to reside outside the white nation-building project leaves much to be wrestled with theoretically. However, Sullivan takes great care to bring to life the "grief and loss" suffered by mobile home park residents during dislocation. The powerful specter of residents witnessing their homes, neighborhoods, and communities dismantled will remain with readers.

Sullivan argues that mobile home parks, the most substantive source of unsubsidized affordable housing for the economically marginalized, came to structure deep housing insecurity because eviction is, at its root, a profitable business. Poverty is a business, and there is profit to be made by capitalizing on the economically marginalized.

Manufactured Insecurity is a much needed, powerful, and authoritative addition to the bourgeoning literature on the relational nature of poverty and sociology of eviction. Sometimes I wished that Sullivan did not become bogged down with offering so many new concepts situated within multiple bodies of work and often uncertain and complex sentences. But perhaps that's the price to pay for such an impressive body of data- each chapter was sometimes its own entity, and this can often take away from the power of the overall story a book leaves you with. Also, while Sullivan does touch upon how class is racialized, a deeper engagement with the implications of white bodies residing in poverty would have further strengthened the work. How does white cultural supremacy shape the construction of "trailer trash" as secondclass citizens? Antipoverty policies are couched in racialized and gendered understandings of black and brown bodies as burdens on the state-how does whiteness play into this? Nonetheless, Manufactured Insecurity is undoubtedly a major contribution that will move the new poverty research agenda forward in the right direction. I will likely use it in graduate seminars and undergraduate classes on inequality and poverty, fieldwork, and urban sociology, among others.

Relational Inequalities: An Organizational Approach. By Donald TomaskovicDevey and Dustin Avent-Holt. New York: Oxford University Press, 2019. Pp. viii+293. \$99.00.

William Finlay

University of Georgia

Is one likely to earn more if, to pick just three factors, one has more education, is male, or is a citizen rather than an immigrant? The answer to all 